\title{
Developing English Language Training Program for Students Depending on Outcome-Based Education: Case Study Ho Chi Minh City Industrial University, Vietnam
}

\author{
Nhat Truong Tran Minh ${ }^{1,2, *}$, Hong Bui Van ${ }^{3}$ \\ ${ }^{1}$ English Teacher at FFL, Industrial University of Ho Chi Minh City (IUH), Vietnam \\ ${ }^{2} \mathrm{PhD}$ Student in Education Study at Ho Chi Minh City University of Technology and Education (HCMUTE), Vietnam \\ ${ }^{3}$ Dean of Institute of Technical Education, Ho Chi Minh City University of Technology and Education (HCMUTE), Vietnam
}

Received March 22, 2021; Revised April 20, 2021; Accepted May 28, 2021

\section{Cite This Paper in the following Citation Styles}

(a): [1] Nhat Truong Tran Minh, Hong Bui Van, "Developing English Language Training Program for Students Depending on Outcome-Based Education: Case Study Ho Chi Minh City Industrial University, Vietnam," Universal Journal of Educational Research, Vol. 9, No. 6, pp. 1233-1243, 2021. DOI: 10.13189/ujer.2021.090612.

(b): Nhat Truong Tran Minh, Hong Bui Van (2021). Developing English Language Training Program for Students Depending on Outcome-Based Education: Case Study Ho Chi Minh City Industrial University, Vietnam. Universal Journal of Educational Research, 9(6), 1233-1243. DOI: 10.13189/ujer.2021.090612.

Copyright $\bigcirc 2021$ by authors, all rights reserved. Authors agree that this article remains permanently open access under the terms of the Creative Commons Attribution License 4.0 International License

\begin{abstract}
Outcome-Based learning is becoming more and more popular worldwide since the 1980 s, and now it is a very vital approach in education. This study aims to examine the satisfaction of undergraduates with their learning outcomes of EFL attainment based on the four English skills which include: listening, speaking, writing, and reading, and also their learning activities perceptions and assessment tasks applied in the class. The study participants involved 300 third or fourth-year students who had completed the four courses of General English (GE) and did different disciplines at Industrial University of Ho Chi Minh City in Vietnam. The study employed both open-ended and closed-ended questionnaires as data collection instruments. Data were analyzed by content analysis and descriptive statistics. From the findings of the study, it was evident that a larger percentage of students were not very satisfied with their learning outcomes, and those students had a negative perception about assessment tasks and learning activities applied in the class. However, a larger percentage of the students were very satisfied with the writing sub-skill. The study recommended that the quality of implementation of the EFL curriculum should be improved particularly at the university and generally at the Vietnamese tertiary level.
\end{abstract}

Keywords Outcome-Based, General English, Learning Outcomes, Tertiary Level, Linguistic Course

\section{Introduction}

Outcome-Based Education (OBE) is the modern systematic methodology to reform curriculum in the sector of schools that is employed by several countries including Australia, South Africa, and the United States. In institutions of higher learning, its crucial implementation has been European Union Universities as a section of the Bologna Process intended to make a European Higher Education Area that is barrier-free (Kennedy, 2020) [12]. In line with (Killen 2015) [13], the approach of OBE enables the efficient use and application of various learning and teaching strategies by the educator, and also the learner. The application of the OBE approach in the classrooms of English Foreign Language (EFL) equips students with competency and skills to use English in crucial situations like during informal and formal interactions. According to (Irons, 2019) [11], learners and educators in the ESL classroom get into processes of communication during the application of strategies like direct instruction, problem-solving, group work, co-operative learning, and performance activities effectively. It is necessary for educators to implement these strategies in ESL learning and teaching. For purposes of completion of the task-based 
activities that are part of the OBE approach, ESL learners need the language skills of reading, writing, listening, and speaking.

In non-English speaking backgrounds like Vietnam, teaching and learning English are specially paid attention to all colleges and universities, because English is compulsory, and it is highly valued by the Ministry of Education and Training (MOET) of the Socialist Republic of Vietnam. And this is the reason the striving Project called "Teaching and Learning Foreign Languages in the National Education System, Period 2008-2020" has been approved and implemented throughout the country.

In Vietnam, various stakeholders including teachers, employers, and managers have taken the English language with a lot of seriousness. The effectiveness of language learning and teaching in different tertiary levels has been measured with the satisfaction of students with their learning outcomes. It does not only allow instructors to acquire information concerning their teaching but also gives responses from parents and managers. The satisfaction of learners has always been a major issue and has gained concern globally. Currently, various studies have been done to examine the satisfaction of students with training curricula at higher education level, for instance, (Abbasi, 2015) [1] investigated satisfaction of students with teaching facilities and activities. However, very limited studies have been done to conclude if the anticipated outcomes are attained, or the extent learners are pleased with their attainment of the specified learning outcome, and whether the applied outcome-based approach is appropriate.

This research was done with a key objective of examining the level of student's satisfaction with their learning outcomes of EFL based on the four macro skills and their perception about assessment tasks and learning activities. The following questions were developed to guide the study.

- How do non-English majored students satisfy with their EFL outcomes based on the four macro skills: speaking, reading, wring, and listening?

- To what level do inside class activities support the undergraduates in attaining the stated outcomes?

- How important do the learners find and perceive the learning assessment tasks to the mentioned English learning outcomes?

I expect that the findings of this study will be helpful in the implementation of EFL courses in the Industrial University of Ho Chi Minh City in Vietnam and the employment of English teachers at the tertiary level.

\section{Literature Review}

\section{What is Outcome-Based Education?}

Outcomes-Based Education aims at designing a curriculum and implementing it focusing on the abilities of learners after the learning process. OBE expects the educators to ask what the teachers expect the learners to study, the reason they want to learn it, how better they want the learners to study it and how will the teachers measure what the learners have obtained. Thus, in OBE there is a selection of the desired outcome first before the creation of curriculum, assessment, and instructional materials to offer support to the desired outcome (Spady 2014) [17]. Outcomes, according to Spady, are "...clear learning results that we want students to demonstrate at the end of significant learning experiences" (1994, p. 2). These outcomes determine the curriculum design. It is a kind of informed teaching and learning. Learners know beforehand what they are going to learn and how they are going to learn what they learn, and the teachers know what their students are expected to learn and how best they will be able to use the learned experience in doing what they are expected to do or to get at the end of the learning process.

\section{The Theory of Outcome-Based Learning and Practice}

The development of OBL focuses on the learning of the student. For instance, Spady (2014) [17] states that "focusing and organizing everything in an educational system around what is essential for all students to be able to do successfully at the end of their learning experiences" and according to Driscoll \& Wood (2017) [8], outcomes-based learning involves an educational approach that cultivates ongoing learning attention of a student and enables answerability of the institution regarding the learning of a student. According to them, OBE is a model of education in which program and assessment are centered on the learning outcomes of the student. Likewise, Kullas (2011) [14] depicts that OBE is a practice that concentrates on what is to be knowledgeable. Outcomes demonstrate learning. They are all the abilities of students after undergoing a learning process. The practice entails "sticking" with the learner up to the point he attains the outcome.

According to (Spady, 2014), outcomes are "not the score, label, grade, or percentage that someone attaches to the demonstration, but the substance and actions of the demonstration itself". Williams (2017) [19] gave features of outcomes which included: they should be assessable and attainable, they should be fair and clear, they should focus on learning results, not process, they should show where students have achieved nothing, and instructions should make a difference. Apparently, Spady depicts categorically that outcomes should indicate what learners can do after they have completed the learning course. Learning is regarded as important only if it offers learners prominence to the life-roles that they are likely to face outside the education system.

Based on the above, it is clear that the main aim of OBL is results. Learning outcomes entails the expectation of an 
individual after undergoing a learning process, which informs the program and assessment. They are meant to offer more efficient learning practices at all education levels. In general, the designing of a particular curriculum begins with what students are anticipated to learn, and is followed by instruction and learning design that might help students to attain the desired learning outcomes, and concludes with the application of assessments that gives response concerning the learning level that has been attained.

In line with the works of Killen (2015) [13], strategies of teaching and learning are described by the manner in which educators use styles, skills, and techniques. There is a need for educators to employ several teaching strategies to enable the students to showcase the learning they have obtained. An example of the strategy is whereby students are allowed to form groups so as to enhance the ESL acquisition. The process should be guided by the ESL educator while students give outputs such as games, dialogues, and role-plays. Such activities enable learners to read, listen and speak (Storti, 2015) [18]. For example, grammar knowledge entails not only the study of particular set rules but also involves learning the good manipulation of language devices in conveying particular meanings.

Kullas (2011) [14] applies strategies of radio programs to help in the teaching and learning of ESL. Radio programs, like talk shows on emerging topics, give learners opportunities to clearly make meaningful expressions and language inputs in the classrooms of ESL. Radio programs also offer learners reliable communication as well as dependable enrichment of language in the outside classroom environment.

In line with the works of Ali (2017) [2], ESL communication facilitates the development of intelligent advancement, lateral and creative thinking so as to match and provide ESL learners with the values of English. When learners communicate and use English, they develop themselves. Learners' competency in communication is hindered by the inability to practice the use of English in ESL classrooms.

Most of the students struggle with activities related to ESL communication because of their lack of proficiency in English. There is a need for ESL educators to shift from an educator-based approach to a student-based approach. This change automatically affects ESL educators' strategies as they are used to the old and traditional methods of teaching. The traditional methods and strategies of teaching in languages hinder the students' perception and this leads to underachievement.

\section{Methodology}

\subsection{Participants}

The study participants involved 344 fourth-year undergraduates who had completed the General English courses at the university and were in their third or final year of study. 300 of them filled and returned the questionnaires which were regarded as a good rate of return. 44 questionnaires were eliminated because they were not complete all expected questions and/or the answers were too short without enough information for the research. The participants were selected randomly using a convenient sampling technique. Prior to collecting data, the researcher took permission from authorities in order to conduct this questionnaire survey. The demographic information of the participants is shown in the table below.

Table 1. Demographic Data of Fourth-year Undergraduates Participants

\begin{tabular}{|c|c|c|c|}
\hline Students & & $\mathrm{N}=300$ & $\%$ \\
\hline Gender & $\begin{array}{ll} & \text { Female } \\
\text { - } & \text { Male } \\
\end{array}$ & $\begin{array}{l}180 \\
120\end{array}$ & $\begin{array}{l}60 \% \\
40 \% \\
\end{array}$ \\
\hline Faculty/Majors & $\begin{array}{ll}\text { - } & \text { Business Administration } \\
\text { - } & \text { Environment and Biology Technology } \\
\text { - } & \text { Tourism and Hinance } \\
\text { - } & \text { Architecture and Construction } \\
\text { - } & \text { Information Technology } \\
\text { - } & \text { Electrical and Electronic Engineering } \\
\text { Economy Law }\end{array}$ & $\begin{array}{l}3 \\
45 \\
36 \\
64 \\
29 \\
24 \\
32 \\
27\end{array}$ & $\begin{array}{c}14.3 \% \\
15 \% \\
12 \% \\
21.3 \% \\
9.6 \% \\
8 \% \\
10.7 \% \\
9 \%\end{array}$ \\
\hline
\end{tabular}




\subsection{Data Collection}

A questionnaire was the main instrument for data collection. The questionnaire was made up of two sections. The first section was closed-ended questions and involved a five-point Liker scale ranging from, "very dissatisfied" (VD), to dissatisfied (D), to neutral (N), and then satisfied (S) to "very satisfied" (VS). This section contained 25 items that came from four main skills: speaking, reading, writing, and listening. In each group, there were distinct features that were developed to measure the satisfaction of the students with their capabilities to apply language after going through the four General English courses in the University. The second section involved a three open-ended questionnaire that asked the learners to give their views concerning the extent learning activities helped them in the attainment of the identified outcomes, and how significant they viewed the tasks of learning assessment to the identified learning desires.

\subsection{Data Analysis}

Data that were obtained from the questionnaires were analyzed by the use of SPSS. Descriptive Statistics based on means, standard deviation, and percentages were summed up so that the respondents' characteristics could be approximated and the satisfaction level with the learning outcome was elaborated. Narrative passages were used to interpret the results from the open-ended questionnaire. Some responses sections were mined and parroted in this paper to give more evidence on the analysis of the results.

\section{Results and Discussion}

\subsection{Students' Satisfaction with Learning Outcomes}

Levels of Students' Satisfaction with Their Reading Skills

This section looks at 6 features concerning the satisfaction levels of learners with reading sub-skills (R) as shown in the following table.

Table 2. Descriptive Statistics for Reading Sub skills

\begin{tabular}{|c|c|c|}
\hline Variable & Sub-scale & $\%$ \\
\hline $\begin{array}{l}\text { R1. Reading real texts on familiar subjects related to their } \\
\text { studying and life. }\end{array}$ & $\begin{array}{ll}\text { - } & \mathrm{VD} \\
\text { - } & \mathrm{D} \\
\text { - } & \mathrm{N} \\
\text { - } & \mathrm{S} \\
\text { - } & \mathrm{VS}\end{array}$ & $\begin{array}{l}5 \\
20 \\
50 \\
15 \\
10\end{array}$ \\
\hline $\begin{array}{l}\text { R2. Understanding the description of events, feelings, } \\
\text { hobbies and everyday life }\end{array}$ & $\begin{array}{ll}- & \mathrm{VD} \\
\text { - } & \mathrm{D} \\
\text { - } & \mathrm{N} \\
\text { - } & \mathrm{S} \\
\text { - } & \mathrm{VS}\end{array}$ & $\begin{array}{l}0 \\
5 \\
55 \\
20 \\
20\end{array}$ \\
\hline $\begin{array}{l}\text { R3. Scanning longer familiar passages or documents in } \\
\text { order to locate desired information }\end{array}$ & $\begin{array}{ll}- & \mathrm{VD} \\
\text { - } & \mathrm{D} \\
\text { - } & \mathrm{N} \\
\text { - } & \mathrm{S} \\
\text { - } & \mathrm{VS}\end{array}$ & $\begin{array}{l}0 \\
10 \\
52 \\
20 \\
18\end{array}$ \\
\hline $\begin{array}{l}\text { R4. Understanding relevant information in everyday } \\
\text { materials }\end{array}$ & $\begin{array}{ll}- & \mathrm{VD} \\
\cdot & \mathrm{D} \\
\cdot & \mathrm{N} \\
\cdot & \mathrm{S} \\
- & \mathrm{VS}\end{array}$ & $\begin{array}{l}0 \\
0 \\
5 \\
15 \\
80\end{array}$ \\
\hline $\begin{array}{l}\text { R5. Identifying specific points in newspaper articles on } \\
\text { familiar topics }\end{array}$ & $\begin{array}{ll}\cdot & \mathrm{VD} \\
\text { - } & \mathrm{D} \\
\text { - } & \mathrm{N} \\
\text { - } & \mathrm{S} \\
\text { - } & \mathrm{VS}\end{array}$ & $\begin{array}{l}5 \\
10 \\
53 \\
12 \\
20\end{array}$ \\
\hline $\begin{array}{l}\text { R6. Understanding clearly written instructions, and } \\
\text { regulations }\end{array}$ & $\begin{array}{ll}\text { - } & \mathrm{VD} \\
\text { - } & \mathrm{D} \\
\text { - } & \mathrm{N} \\
\text { - } & \mathrm{S} \\
\text { - } & \mathrm{VS}\end{array}$ & $\begin{array}{l}0 \\
10 \\
50 \\
14 \\
26\end{array}$ \\
\hline
\end{tabular}


As depicted in Table 2 above, feature R1 data analysis indicated that $10 \%$ of the learners thought that they are capable of reading factual texts on subjects that were familiar, which is associated with their area and interest with an agreeable level of comprehension, and $20 \%$ of them believed that they are capable of understanding the description of events, wishes in personal letters and feelings (R2). $18 \%$ of them (R3) believed that they can scan longer family text so as to locate the desired information. In feature 4, there was the highest occurrence of learners' highest level of satisfaction, which was an indication of $80 \%$ of them believing they are capable of understanding relevant information in everyday material. Based on the capability of identifying specific points in newspaper articles or familiar subjects (R5), $20 \%$ of them believed they are capable. And lastly, based on the understanding of clearly written regulations and instructions, $26 \%$ of them were satisfied (R6). Though, almost half of the learners had ratings that were neutral concerning the features of their reading skills. These findings indicate that the curricula book did not look at different kinds of reliable reading texts and hence the learners didn't have any opportunity to have a look at those reading texts. In addition, learners may only be reading and learning with the coursebook in their lessons and never read other resources away from the classroom.

The findings indicated that the satisfaction level of students with reading sub-skills was average. This could be attributed to the long-time exposure of three to seven years of studying English in their previous secondary schools prior to joining universities. Apparently, in secondary schools, reading in combination with grammar is the most commonly taught skill. This skill is regarded as the simplest skill by learners in the University. Furthermore, every unit in the coursebook entails 2 to 3 reading passages which equips both students and teachers with reading skills. The findings also depicted that the instructors might place more significance in teaching reading skills to learners.

\section{Satisfaction Levels of Students with Their Listening Skill}

This subcategory looks at 4 features concerning the intensities of satisfaction of learners with listening sub-skills (L) as shown in the following table.

Table 3. Descriptive Statistics for Listening Skills

\begin{tabular}{|c|c|c|}
\hline Variable & Sub-scale & $\%$ \\
\hline L1. Understanding detail information about common daily or job & $\begin{array}{ll}\text { - } & \mathrm{VD} \\
\text { - } & \mathrm{D} \\
\text { - } & \mathrm{N} \\
\text { - } & \mathrm{S} \\
\text { - } & \mathrm{VS}\end{array}$ & $\begin{array}{c}0 \\
5 \\
55 \\
10 \\
30\end{array}$ \\
\hline L2. Understanding the main idea of clear speech on similar topics & $\begin{array}{ll}\text { - } & \mathrm{VD} \\
- & \mathrm{D} \\
\text { - } & \mathrm{N} \\
\text { - } & \mathrm{S} \\
\text { - } & \mathrm{VS}\end{array}$ & $\begin{array}{c}5 \\
10 \\
40 \\
15 \\
30\end{array}$ \\
\hline $\begin{array}{l}\text { L3. Understanding the main points of discussion, short talks on } \\
\text { familiar topics }\end{array}$ & $\begin{array}{ll}\text { - } & \mathrm{VD} \\
\text { - } & \mathrm{D} \\
\text { - } & \mathrm{N} \\
\text { - } & \mathrm{S} \\
\text { - } & \mathrm{VS}\end{array}$ & $\begin{array}{c}10 \\
20 \\
55 \\
5 \\
10\end{array}$ \\
\hline L4. Understanding simple instructions or detailed directions & $\begin{array}{ll}\text { - } & \mathrm{VD} \\
\text { - } & \mathrm{D} \\
\text { - } & \mathrm{N} \\
\text { - } & \mathrm{S} \\
\text { - } & \mathrm{VS}\end{array}$ & $\begin{array}{c}5 \\
15 \\
35 \\
34 \\
11\end{array}$ \\
\hline
\end{tabular}


As shown in Table 3 above, feature L1 data analysis depicted that $30 \%$ of the learners believed that they are capable of understanding detail information concerning popular daily activities or job correlated topics; an equal percentage of them $(30 \%)$ depicted that they were satisfied with their capability to comprehend the key ideas of clear speech on familiar topics in work, leisure and school; though, in item LS3 there was an occurrence of the least level of students' satisfaction. Only $10 \%$ of them (L3) were capable of understanding the main points of discussion, short talks on familiar topics. An almost equal percentage (11\%) of them were pleased with feature L4 concerning their capability to understanding simple operating instructions or detailed directions. Though, at least one-third of the learners had neutral ratings concerning their listening skills. The percentages indicate that these learners depicted average listening ability. They did not trust if they were capable of performing the above-mentioned listening skills.
From the results, it was clear that the level of student's satisfaction with listening skills was slightly higher compared to those with speaking skills. This could be attributed to the several listening activities designed in the coursebook and it was mandatory for the instructors to cover them during instructions. Another reason behind this could be due to testing of listening skills in achievement tests. More so, the teachers gave more emphasis on classrooms because they did not want the students to fail the test.

\section{Levels of Students' Satisfaction with Their Speaking Skill}

This subcategory measures five features concerning levels of students' satisfaction with spoken production sub-skills (SP) as illustrated in tables 5 below

Table: 4. Descriptive Statistics for Spoken Production Skills

\begin{tabular}{|c|c|c|}
\hline Variable & Sub-scale & $\%$ \\
\hline $\begin{array}{l}\text { SP1. Describing a variety of familiar } \\
\text { subjects }\end{array}$ & $\begin{array}{ll}\text { - } & \mathrm{VD} \\
\text { - } & \mathrm{D} \\
\text { - } & \mathrm{N} \\
\text { - } & \mathrm{S} \\
\text { - } & \mathrm{VS} \\
\end{array}$ & $\begin{array}{c}40 \\
25 \\
10 \\
5 \\
10\end{array}$ \\
\hline $\begin{array}{l}\text { SP2. Describing experiences, feelings, and } \\
\text { reactions }\end{array}$ & $\begin{array}{ll}\text { - } & \mathrm{VD} \\
\text { - } & \mathrm{D} \\
\text { - } & \mathrm{N} \\
\text { - } & \mathrm{S} \\
\text { - } & \mathrm{VS} \\
\end{array}$ & $\begin{array}{c}20 \\
5 \\
5 \\
10 \\
60\end{array}$ \\
\hline $\begin{array}{l}\text { SP3. Describing daily activities, hopes, and } \\
\text { plots of books or films or real things in life }\end{array}$ & $\begin{array}{ll}\text { - } & \mathrm{VD} \\
\text { - } & \mathrm{D} \\
\text { - } & \mathrm{N} \\
\text { - } & \mathrm{S} \\
\text { - } & \mathrm{VS}\end{array}$ & $\begin{array}{c}10 \\
20 \\
50 \\
15 \\
5\end{array}$ \\
\hline $\begin{array}{l}\text { SP4. Giving reasons, and explanations or } \\
\text { arguments }\end{array}$ & $\begin{array}{ll}\text { - } & \mathrm{VD} \\
\text { - } & \mathrm{D} \\
\text { - } & \mathrm{N} \\
\text { - } & \mathrm{S} \\
\text { - } & \mathrm{VS}\end{array}$ & $\begin{array}{c}5 \\
10 \\
55 \\
15 \\
15\end{array}$ \\
\hline $\begin{array}{l}\text { SP5. Giving clear presentations of familiar } \\
\text { topics }\end{array}$ & $\begin{array}{ll}\text { - } & \mathrm{VD} \\
\text { - } & \mathrm{D} \\
\text { - } & \mathrm{N} \\
\text { - } & \mathrm{S} \\
\text { - } & \mathrm{VS}\end{array}$ & $\begin{array}{c}60 \\
10 \\
5 \\
5 \\
20\end{array}$ \\
\hline
\end{tabular}


As designated in Table 4 above, a small percentage of learners were pleased with their skills of spoken production. Feature SP1 data analysis indicated that only $10 \%$ of the learners were capable of describing a variety of familiar subjects in the area of interest. Consequently, $20 \%$ of them (SP2) revealed that they were not capable of describing experiences, reactions, and feelings in English. This factor attained the highest levels of satisfaction of the learners; but only $5 \%$ of them (SP3) testified that they can describe daily activities, hopes, and plots of books or films or real things in our life. This category of speaking sub-skill could be the hardest for the learners although books and films are not very strange with students. Based on the capability of giving reasons and explanations for opinions or arguments, only $15 \%$ of them (SP4) were satisfied with this sub-skill. Based on feature SP5, 20\% testified that they are capable of giving clear presentations of familiar topics. Though, more than one-third of the learners had neutral ratings concerning the five features about their spoken production skills. The percentages could indicate that these learners were unsure about their ability to speaking. It could be that their ability of speaking was not tested upon completion of the five courses.

From the analysis of data of the five factors, it was evident that learners nearly had similar perceptions concerning their sub-skills of spoken production. Only a few of them were satisfied with their capabilities of speaking. A large number of the students were not satisfied with their speaking abilities. It was clear that in the course of class instructions, learners didn't have enough chances to do the practice on speaking skills. The teachers didn't ask them to make presentations that were related to these themes or there is a chance that no projects were assigned to learners at all in each unit. Another reason behind this occurrence could be that the course's objectives and goals were not sufficient and very clear. Teachers did not ask them to conduct these activities in classrooms; and because of limited time in classrooms, in the circumstances of occurrence of any hard tasks, they might do away with them for the sake of saving time. Overall, the curriculum did not meet the expectations of the students with respect to spoken production skills.

\section{Levels of Students' Satisfaction with Their Writing Skills}

This section looks at 4 features concerning the satisfaction levels of students with writing sub-skills (W) as shown in the following table.

Table 5. Descriptive Statistics for Writing Skills

\begin{tabular}{|c|c|c|}
\hline Variable & Sub-scale & $\%$ \\
\hline $\begin{array}{l}\text { W1. Writing descriptions of popular topics } \\
\text { within their field of interest or things around } \\
\text { their daily }\end{array}$ & $\begin{array}{ll}\text { - } & \mathrm{VD} \\
\text { - } & \mathrm{D} \\
\text { - } & \mathrm{N} \\
\text { - } & \mathrm{S} \\
\text { - } & \mathrm{VS}\end{array}$ & $\begin{array}{c}0 \\
5 \\
5 \\
20 \\
70\end{array}$ \\
\hline $\begin{array}{l}\text { W2. Writing short, simple paragraphs, } \\
\text { essays and reports in about } 100-300 \text { words }\end{array}$ & $\begin{array}{ll}\text { - } & \mathrm{VD} \\
\text { - } & \mathrm{D} \\
\text { - } & \mathrm{N} \\
\text { - } & \mathrm{S} \\
\text { - } & \mathrm{VS} \\
\end{array}$ & $\begin{array}{c}0 \\
5 \\
10 \\
10 \\
75\end{array}$ \\
\hline $\begin{array}{l}\text { W3. Writing personal letters expressing } \\
\text { idea, feelings, suggestions about similar } \\
\text { topics }\end{array}$ & $\begin{array}{ll}\text { - } & \mathrm{VD} \\
\text { - } & \mathrm{D} \\
\text { - } & \mathrm{N} \\
\text { - } & \mathrm{S} \\
\text { - } & \mathrm{VS} \\
\end{array}$ & $\begin{array}{c}0 \\
0 \\
5 \\
5 \\
90\end{array}$ \\
\hline $\begin{array}{l}\text { W4. Writing messages and notes in daily } \\
\text { communication, work and study }\end{array}$ & $\begin{array}{ll}\text { - } & \mathrm{VD} \\
\text { - } & \mathrm{D} \\
\cdot & \mathrm{N} \\
\text { - } & \mathrm{S} \\
\text { - } & \mathrm{VS}\end{array}$ & $\begin{array}{c}0 \\
10 \\
10 \\
20 \\
60\end{array}$ \\
\hline
\end{tabular}


As indicated in Table 5 above, a large percentage of learners were very satisfied with their writing skills. None of the students indicated that he/she was very dissatisfied with the skill. Feature W1 data analysis indicated that $70 \%$ of the learners were capable of writing descriptions of similar topics within their area of interest. Similarly, $75 \%$ of the learners were capable of writing short and simple reports (W2). $90 \%$ of the learners testified that they can write personal letters conveying their idea, suggestion and feelings about their familiar topics (W3) and $60 \%$ of the learners were very satisfied that they could write messages and notes in everyday communication with friends, family members and so on (W4).

The findings indicated that a larger percentage of the students were very satisfied with the writing skills. These results are shockingly quite different compared to data that was obtained from other skills. It was clear that in the course of class instructions, teachers usually focus on grammar, vocabulary teaching, and other writing skills. Teachers also helped the students to do their exercises. This could be the reason behind the high percentage of satisfaction of learners with regard to this skill.

\subsection{Students' Perceptions about Learning Activities}

The aim of the second research question was to examine the degree learning activities gave support to the learners in attaining the identified learning outcomes. From the analysis of data from the questionnaire, it was evident a small percentage of the learners had perceived that learning activities facilitated their attaining of learning outcomes.

For instance, 15 learners stated:

"....... in the English lessons, the teacher usually requests us to share or discuss ideas in groups concerning some topics after reading text, or when listening to narrated story, we also discuss about the themes of the story.... Some of us really like to speak and express our thought, but some my friends are lazy, they talk nothing"

Automatically, the findings of the research indicated that during the course implementation, at least a few learners were capable of understanding what was being taught. Nevertheless, the learners with a positive perception about the instructions of teachers might be more able learners, who believed that the activities were significant to their language proficiency level. They were capable of understanding the texts, and doing topic discussions, and thus attaining their learning results. This finding was in line with the results of the closed-ended questionnaire which indicated that approximately one-third of the learners were satisfied with their learning outcomes and due to the higher satisfaction levels those learners scored higher grades and had a higher probability of completing their program. According to (Gecer, 2017) [9], students are regarded as satisfied if they believe that the lessons meet their expectations and needs (Gecer, 2017).
However, approximately two-thirds of the learners didn't believe that learning activities applied in class boosted their attainment of the learning desires. For instance, many learners stated:

“... Learning activities must focus on the learners more and more, and not the instructor. Some lazy students like to study with the teachers who talk all times, and we do not have to do anything. The learners work less than the instructor. Instructors only rely on the coursebook. ...."

With regard to the learning outcomes provided in the program, it can be concluded that all learners were expected to be capable of using English in everyday conditions which were described in the statements of learning outcome. How can the learners be pleased with their learning results if learning activities conducted in classrooms were below their expectations? Apparently, the satisfaction of learners reveals the efficiency of instruction. In circumstances where teachers concentrated on instructions of high quality and developed chances for learners to develop their skills in English, they could aid in the maintenance of high levels of student satisfaction.

More shockingly, a large number of learners protested that instructors only explained or read and told the learners to write what was regarded to be of importance. Less time was spent on activities of skills development. For instance, 2 learners stated:

“.... The instructor should make application of cooperating teaching technique, avoid explaining. listening time should be greater than before and there should be a provision of topics for the learners to do training of speaking...., or ".... The instructor should be extra active during lessons. There should be organization of activities where learners communicate with each other in English...."

Based on the aforementioned views, it is evident that few communication activities were offered for the learners to enhance their skills of speaking and less time was employed on the English skills improvement. It appeared that the instructors still mainly preferred old-style approaches of teaching which majorly was based on the explanation.

With regard to the responses of learners on the questionnaire, it could be concluded that a majority of the learning activities applied in the class didn't give abundant support to the learners in the attainment of the desired learning outcomes. The findings could be the explanation of the reasons why the satisfaction intensities of learners were low concerning the learning outcomes. An assumption can also be made that most EFL teachers at the tertiary level didn't obtain enough in-service training regarding outcome-based training and learning values in EFL training. The results of research done by Schlebusch and Thobedi (2015) [16] indicated that the main issue with some of the teachers is that they didn't obtain advanced teaching on how to raise the ESL teaching level and 
learning with appropriate approaches.

\subsection{Learning Assessment Tasks}

The aim of research question three was to examine how significant the learners perceived the learning assessment tasks to the identified learning outcomes.

\section{Formative Assessment Tasks}

With respect to the works of Brookard (2019) [6], a formative assessment is regarded as successful if it focuses learner work plainly on learning outcomes or learning targets; enables instructors and learners to gauge growth against the goal; and provides information suitable for development. However, the responses of students on the questionnaires exposed that several learning assessment activities applied in the classroom were not appropriate to the learning outcomes. For instance, almost 20 learners stated:

“......in my classes, most of the teachers applied assessment techniques like yes-no questions, vocabulary completing, multiple-choice, true-false questions and listening and reading comprehension....", or “... development of students' skills should be given more emphasis by the teachers, than just giving them exercises for the sake of passing exams...", or "... as a replacement for of doing multiple-choice exams, teachers should give students assignments of writing short essays weekly while at home and later correct in class ...."

In line with (Maki, 2017) [15], learning outcomes designate what learners should know and be capable of doing. That means that during instructions, there is a need for assessment of both skills and language knowledge. However, the results depicted that instructors only assessed the English knowledge of learners such as grammar structures or vocabulary.

These findings of the research indicated that instructors used irrelevant formative assessment practices to gauge students' performance instead of knowledge of students or receptive skills. Apparently, several practices or tools for formative assessment like questions and answers, peer-assessment, practical exercises, observation of performance, tests, idea sharing, self-assessments, and journals (Angelo \& Cross, 2019; Irons, 2019) [3] [11] were not applied in the course of instruction. Regardless of the extent, the learning outcomes were attractive, coherent, comprehensible, and attainable (Baume, 2017) [4], the course could not be applied with success with the absence of the relevant assessment tasks of the teacher. Outcomes assessment advances the learning of students so it is crucial to analytically assess the performance of the student on particular learning outcomes (Cartwright, Weiner, \& Streamer-Veneruso, 2015) [7].

\section{Summative Assessment}

The students had to take the end-term exam after completion of one course. When answering the questionnaire, most of the learners claimed that:

".... we all do a multiple-choice exam during the end term exam... the university also doesn't put into consideration speaking skills...they only emphasize on reading and writing... the instructors must come up with the best assessment method based on learner's ability.

In reality, multiple-choice should not be used as a tool to gauge students' performance. Students have different capabilities and one of them is answering multiple-choice items. From the results, it was evident that the technique of using multiple-choice to test the attainment and ability of learners was not consistent with the learning desires.

It is clear that the use of multiple-choice exams during the end-of-term evaluation had a negative impact on the teaching method of teachers. It was revealed that summative assessment did not meet the requirements and expectations of learners. These results go hand in hand with the work of Brindley's study (1998) [5] who discovered that teachers face a lot of challenges in merging summative and formative assessment.

\subsection{Diagnostic Assessment}

The diagnostic assessment encompasses the collection and assessment of in-depth information to identify the strengths and areas that need improvement in any student's work. The information enables the teachers to come up with the best teaching techniques that are suitable to the learners. In line with the learners' responses from the questionnaires, it was clear that the learning assessments that were applied by the instructors did not meet their requirements. For example, most of the learners stated:

" ...the instructors should also put more concentration on organizing activities that will enable the learners to interact with each other and build their speaking skills and not just focusing grammar for the sake of passing exams", or "I don't enjoy my English classes because they are boring. Teachers only focus on grammar. We rarely practice other skills...."

Diagnostic assessment is very crucial in any process of learning because it offers measures that can be used to evaluate the students' strengths and weaknesses so as to come up with the best remedy. With respect to the works of Maki (2017) [15], diagnostic assessment enhances the process of teaching and learning in schools as it portrays the effectiveness or ineffectiveness of a particular school curriculum. In situations where diagnostic assessment is implemented appropriately, the outcome is usually very positive and effective as it improves the learner's performance in the acquisition of skills. 


\subsection{Discussion}

The findings of the study revealed that the satisfaction level of students with reading sub-skills was average. This could be attributed to the long-time exposure of three to seven years of studying English in their previous secondary schools prior to joining universities. Apparently, in secondary schools, reading in combination with grammar is the most commonly taught skill. This skill is regarded as the simplest skill by learners in the University. Also, it was clear that the level of student's satisfaction with listening skills was slightly higher compared to those of speaking skills. This could be attributed to the several listening activities designed in the coursebook and it was mandatory for the instructors to cover them during instructions. Another reason behind this could be due to testing of listening skills in achievement tests. More so, the teachers gave more emphasis on classrooms because they did not want the students to fail the test. A large number of the students were not satisfied with their speaking abilities. It was clear that in the course of class instructions, learners didn't have enough chances to do the practice on speaking skills. The teachers didn't ask them to make presentations that were related to these themes or there is a chance that no projects were assigned to learners at all in each unit. Another reason behind this occurrence could be that the course's objectives and goals were not sufficient and very clear. However, a larger percentage of the students were very satisfied with the writing skills. This is because teachers usually focus on grammar, vocabulary teaching, and other writing skills during lessons. Based on students' perception about learning activities, it was evident that few communication activities were offered for the learners to enhance their skills of speaking and less time was employed on the English skills improvement. It appeared that the instructors still mainly preferred old-style approaches of teaching which majorly was based on the explanation. This finding supports the work of Schlebusch and Thobedi (2015) [16] who discovered that the main issue with some of the teachers is that they didn't obtain advanced teaching on how to raise the ESL teaching level and learning with appropriate approaches. With regard to learners' perception of learning assessment tasks, it was clear that instructors used irrelevant assessment practices to gauge students' performance instead of knowledge of students or receptive skills. This result goes against the works of (Cartwright, Weiner, \& Streamer-Veneruso, 2015)[7] who stated that Outcomes assessment advances the learning of students so it is crucial to analytically assess the performance of the student on particular learning outcomes.

\section{Conclusions}

The findings of the research indicated that the level of satisfaction of learners with the learning outcomes or their proficiency in English with respect to the four skills: listening, writing, reading, and speaking were not very high as expected. The results indicated that the instructions giving of the four skills were not efficiently applied and that the maximum of the teaching and studying time was spent on exercises of grammar and test preparation. Every curriculum must have specified learning outcomes. They need to be inclusive and emphasized the curriculum implementation (Gallavara \& Suominen, 2018) [10]. The findings of the research also revealed assessment tasks and learning activities did not give support to learners in the attainment of their learning outcomes. Learning outcomes should go hand in hand with learning activities and assessment tasks and due to this, there could be the attainment of a large level of student satisfaction. The findings of this study supported the works of Storti (2015) [18]who discovered that learners were not very satisfied with the present Basic English courses. It can be alleged that the low levels of satisfaction of the learners with their learning outcome partially were due to the application of the EFL curriculum, and also teaching and assessment methods applied in classes.

\section{Recommendations}

In line with the findings of the research, various recommendations are provided to EFL teachers and course designers. The study recommended that the designers of courses should equip English language instructors with techniques of outcome-based education through workshops, assessment, and learning, and equipping them with knowledge of the relevance of learning outcomes in relation to learning activities and assessments. With good understanding, they will direct their teaching process correctly to the outcomes of the courses. Necessities and standards for learning assessment in relation to the learning outcomes should be developed and presented to both students and instructors at the start of each course. Also, the research recommends that multiple-choice examinations be substituted with performance assessments. Because the students were very satisfied with writing and speaking skills, the study recommended that the program should focus more on listening and speaking activities, because productive skills are necessary.

\section{REFERENCES}

[1] Abbasi, N. M. (2015). A study on student satisfaction in Pakistani Universities: The case of Bahauddin Zakariya University, Pakistan. Asian Social Science, 7 (7), 209-219.

[2] Ali, N. S. (2017). Evaluation of traditional classroom teaching methods versus course delivery via the World Wide Web. Journal of Nursing Education, 38(6), 272-277. 
[3] Angelo, T. A. \& Cross, K. B. (2019). Classroom assessment techniques: A handbook for college teachers (2nd ed.). San Francisco, CA: Josszy-Bass Publishers.

[4] Baume (2017). Outcomes-based approaches to teaching, learning \& curriculum. Powerpoint presentation on 15 December 2005 for Hong Kong Polytechnic University, Hong Kong.

[5] Brindley.G (1998). Outcomes-based assessment and reporting in language learning programmes: a review of the issues. Macquarie University.

https://doi.org/10.1177/026553229801500103

[6] Brookart, S. M. (2019). Assessment and examinations. In L. J. Saha \& A. G. Dworkin (Eds.). International handbook of research on teachers and teaching (pp.723-738). New York: Springer Science \& Business Media

[7] Cartwright, R., Weiner, K., and Streamer-Veneruso, S. (2015). Student learning outcomes assessment handbook, Montgomery College Montgomery County, Maryland

[8] Driscoll, A., \& Wood, S. (2017). Developing outcomes-based assessment for learner-centered education: A faculty introduction. Stylus Publishing, LLC..

[9] Gecer, A (2017). Lecturer-student communication in blended learning environments. Educational Sciences: Theory \& Practice, 13(1), 362-367.

[10] Gallavara, G. \& Suominen, T. (2018). Learning outcomes: Common framework - different approaches to evaluating learning outcomes in the Nordic countries. European Association for Quality Assurance in Higher Education. Retrieved from http://www.enqa.eu/pubs.lasso
[11] Irons, A. (2019). Enhancing learning through formative assessment and feedback. New York: Routledge.

[12] Kennedy, D., Hyland, Á., \& Ryan, N. (2020). Learning outcomes and competences. Introducing Bologna objectives and tools, 2-3.

[13] Killen, R. (2015). Outcomes-based education: Principles and possibilities. Unpublished manuscript, University of Newcastle, faculty of education.

[14] Kullas , W. (2011). Designing and implementing outcome-based learning in a linguistics course: a case study in Hong Kong. Procedia-Social and Behavioral Sciences, 12, 9-18.

[15] Maki, P. L. (2017). Assessing for learning: Building a sustainable commitment across the institution. Sterling, VA: Stylus.

[16] Schlebusch, G., \& Thobedi, M. (2015). Outcomes-based education in the English

[17] Spady, W. G. (2014). Outcome-Based Education: Critical Issues and Answers. American Association of School Administrators, 1801 North Moore Street, Arlington, VA 22209 (Stock No. 21-00488; \$18.95 plus postage).

[18] Storti, S. B. M. (2015) Outcome-Based Education (Obe) Implementation In Communicative English Classroom: Polytechnic Shah Alam Lecturers' Perspective.

[19] Williams, A. M., Ford, P. R., Eccles, D. W., \& Ward, P. (2017). Perceptual - cognitive expertise in sport and its acquisition: Implications for applied cognitive psychology. Applied Cognitive Psychology,25(3), 432-442. 